\title{
Becoming Citizens Architects
}

A Reflection on Architectural

\section{Education Across the Nordic}

\section{Baltic Academy of Architecture NBAA}

MASSIMO SANTANICCHIA

Iceland University of the Arts 
This paper is the result of multiple forms of inquiry on architectural education across the sixteen schools of architecture part of the Nordic Baltic Academy of Architecture NBAA.

In particular it reports the following:

- Fourteen in-depth conversations conducted with architectural students during October, November, December 2018, and January 2019 across eleven schools of architecture part of the NBAA: KADK in Copenhagen, Chalmers in Gothenburg, AHO in Oslo, BAS in Bergen, VGTU in Vilnius, VDA in Vilnius, RTU in Riga, EKA in Tallinn, Aalto in Helsinki, NTNU in Trondheim, and IUA Iceland University of the Arts in Reykjavik.

- A workshop on architectural education with the second-year students in architecture conducted at the IUA.

- A reflection based on a questionnaire posed to all second-year students at the IUA (architecture, fashion, visual communication, and product) and international students who came to lceland to participate to the multidisciplinary six-week live project called 'Together 2019 a Platform for Citizenship Design'.

The eleven schools were visited for at least three days period. During the visit three extensive interviews were conducted with the program director of the school, educators, and students. In total forty-six direct open-ended interviews took place between October 2018 and January 2019. This paper focuses in reporting the student's voices across northern Europe. Four questions were initiating the discussions with the students:

1 What skills should students have after studying architecture? Or what skills would you like to have upon finishing architecture?

2 How should these skills be taught?

What pedagogies are appropriate or likely to be effective? How would you like to work to achieve those skills? What kind of experience would you like to have to achieve those skills?

3 How can the education of an architect be of special importance to our society?

How can we help you as educators to be of social importance? What ideas can we develop in a school to achieve that goal. How can you contribute in the society through your profession and how can we as school can we help you?

4 Where do you see yourself professionally in 10 years' time? What type of architect you want to be? 
Question number three is a sensitizing concept. Which is also the result of my personal experience both as architect and as educator in architecture. I have been teaching for fifteen years and I have sensed a growing desire on the behalf of the students to use architectural education as a way to get closer to real people and real case studies, to form direct forms of engagement and collaboration with their own community. So, this 'sensitizing concept' has been used as a tentative tool for developing the idea on citizenship, intended as awareness and engagement, through architectural education. This sensitizing concept was a way to start this inquiry and not to end it.

The collected recorded interviews were then transcribed and analysed through the work of Kathy Charmaz Constructing Grounded Theory. Grounded theory methods are based on a consistent and yet flexible guidelines for collecting and analysing qualitative data to then construct theories. Together with interviews basic quantitative data were also gathered from each school to define students' learning umwelt.

This academic paper documents both the vast variety in which architecture education is manifested across the schools of the NBAA network and also reflects on the current students' understanding and doubts on their architectural education, dreams and goals on their future as professionals and citizens. By analysing the findings of these interviews, a consequent theory has been sketched. The theory suggests that a meaningful architectural education should support primarily critical thinking - social awareness and action, by inciting students to become political figures, agents of spatial and social change. I call this theory cosmopolitan citizenship in architecture.

Cosmopolitan is defined as the person whose primary allegiance is to the community of human beings in the entire world (Nussbaum, 1994) whilst citizenship education is intended as a critical tool to develop social awareness and action (Giroux, 1980). Socially active students are the genesis to develop socially responsible citizenship designers (Lorentsen \& Torp, 2018; Guðjohnsen, 2017; Resnick, 2016).

Cosmopolitan citizenship education creates a theoretical scaffolding that can help students seeing and understanding their responsibilities as architects within the society within they operate. In this theory architecture is intended not just as a physical object but as the social relations that are embedded in the process of making architecture (Deamer, 2015). The findings confirm the statement by American designer Milton Glaser that 'good design is good citizenship' (Heller, Vienne, 2003: ix) that is a good design education empowers students to want to be more powerful citizens. 


\section{RESOURCES}

Deamer, P. ed. (2015). The Architect as Worker, Immaterial Labour, the Creative Class, and the Politics of Design. London: Bloomsbury Academic.

Charmaz, K. (2014). Constructing Grounded Theory. Thousand Oaks: Sage Publications.

Giroux, H. (2011). On Critical Pedagogy. London: Bloomsbury. Giroux, H. (1980). Critical Theory and Rationality in Citizenship Education, Curriculum Inquiry, Vol. 10, No. 4 (Winter, 1980), pp. 329-366 Published by: Blackwell Publishing on behalf of the Ontario Institute for Studies in Education/ University of Toronto

Guðjohnsen, R. P. (2016). Young People's Ideas of What It means to be a Good Citizen. The Role of Empathy, Volunteering and Parental Styles (published doctoral dissertation). University of Iceland, Reykjavik, Iceland.

Heller, S. and Veronique Vienne eds (2003). Citizen Designer: Perspectives on Design Responsibility, New York: Allworth Press

Lorentsen, E. \& Torp, K.A. eds (2018). Formation, Architectural Education in a Nordic Perspective. Copenhagen: Nordic Baltic Academy of Architectural, Publisher B.

Nussbaum, M. (1994). Patriotism and Cosmopolitanism, The Boston Review.

Resnick, E. (2016). Developing Citizen Designers. New York: Bloomsbury Academic.

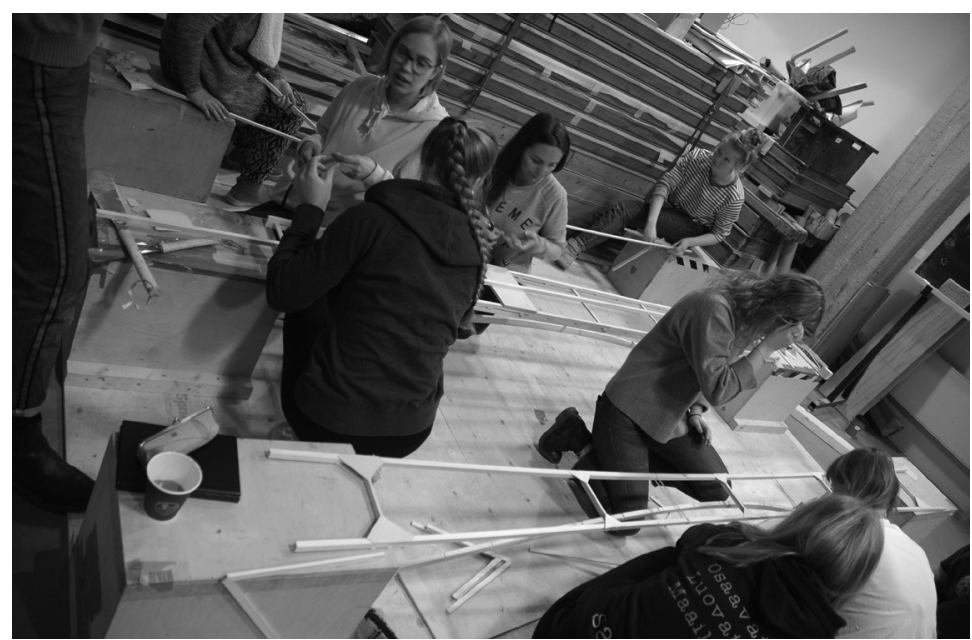




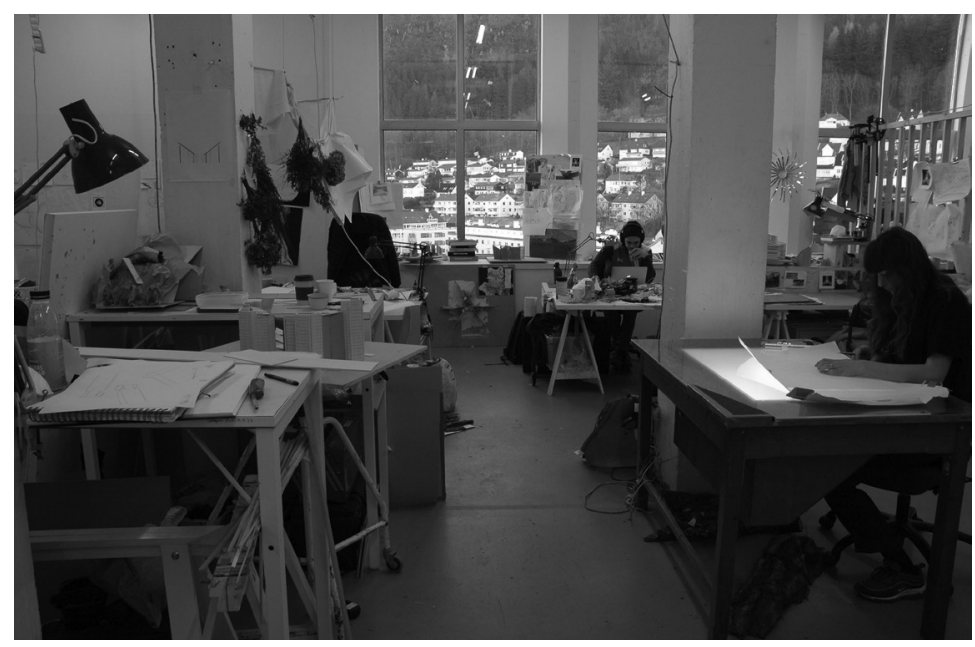

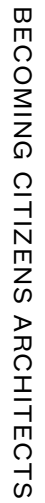

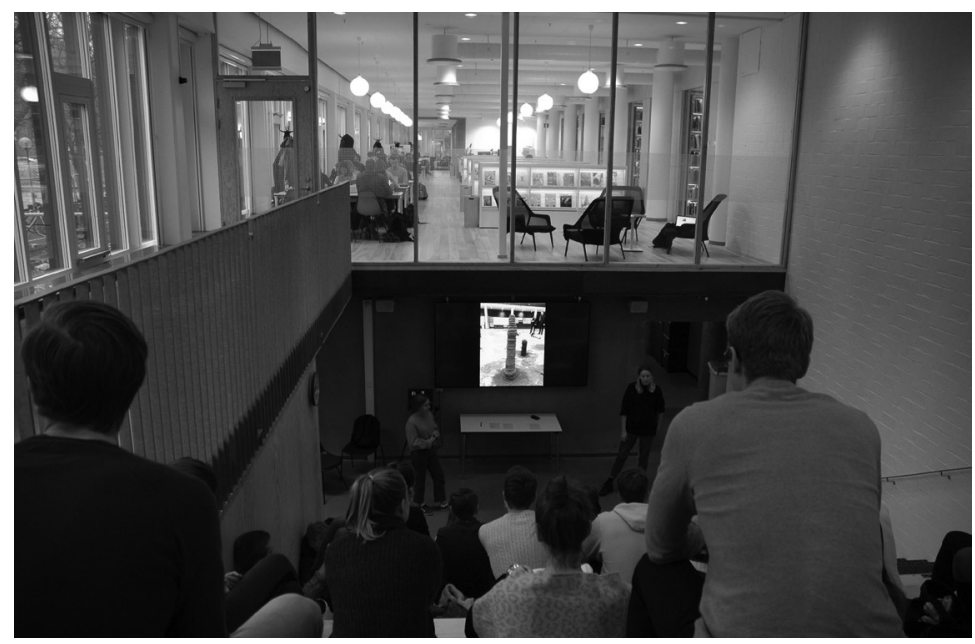

बे 
The images portray five different architectural studios. Aalto in Helsinki, BAS in Bergen, Chalmers in Gothenburg, EKA in Tallinn, and KADK in Copenhagen. All pictures are taken by the author.
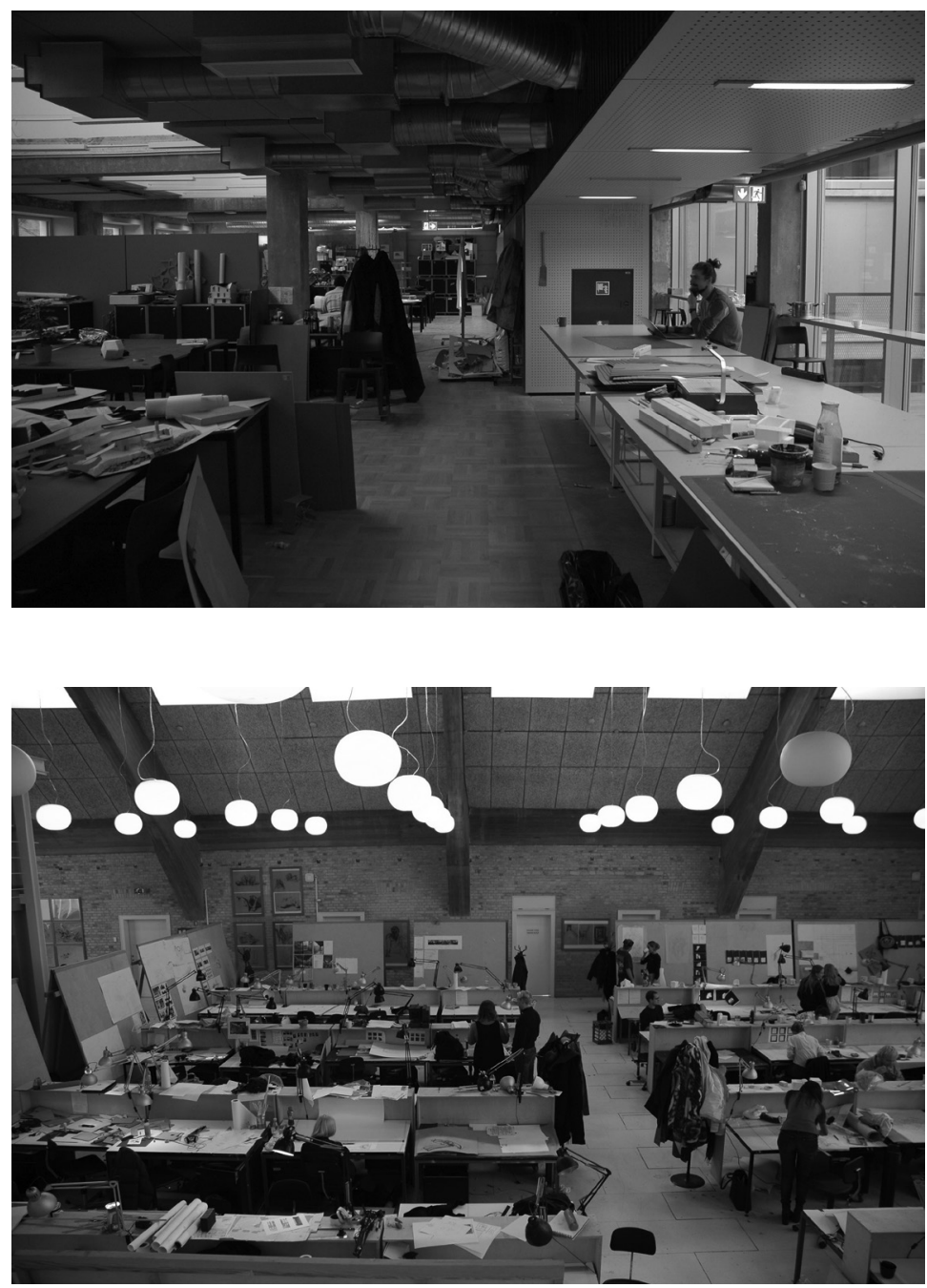